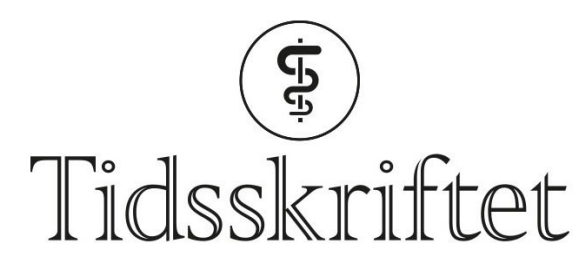

DEN NORSKE LEGEFORENING

\title{
Mennesket og makrofagen
}

ESSAY

\section{RAGNHILD ØRSTAVIK}

E-post: ragnhild.orstavik@tidsskriftet.no

Ragnhild Ørstavik er assisterende sjefredaktør i Tidsskriftet. Hun er dr.med. og har en bistilling som seniorforsker ved Folkehelseinstituttet.

Forfatteren har fylt ut ICMJE-skjemaet og oppgir ingen interessekonflikter.

Barbara Ehrenreich er rasende på makrofager, maktmennesker og multimillionærer. Og leger. Fortsetter hun slik, kommer hun til å dø.

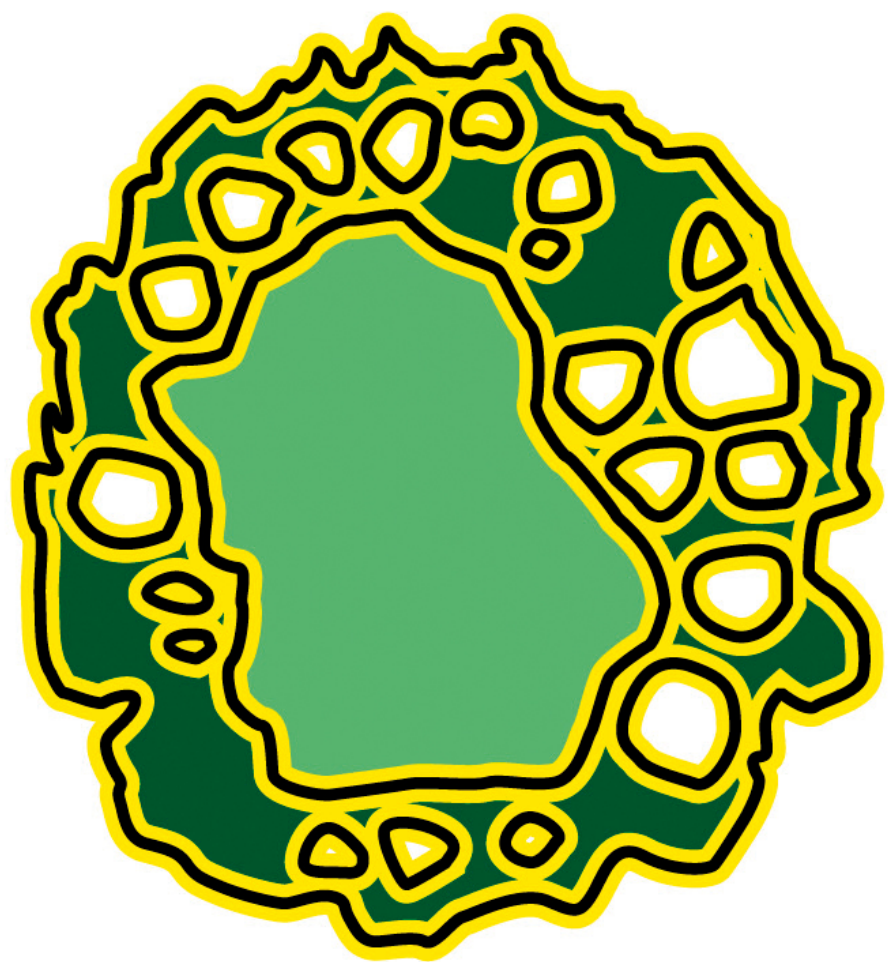

Illustrasjoner: Hilde Lorentzen / Tidsskriftet

Da den nå 77 år gamle feministen, aktivisten og cellebiologen Barbara Ehrenreich tok doktorgrad i immunologi på 196o-tallet, utviklet hun et nært vennskap med makrofagen: Den var immunforsvarets vaktmester, en blåsnipparbeider som fjerner bakterier og virus, døde celler og cellerester. Så - femti år senere - oppdaget hun at makrofager også spiller en viktig rolle for ernæring av kreftsvulster, og at de er essensielle for at blant annet brystkreftsvulster kan metastasere og dermed drepe. Ehrenreich tok dette personlig. I tillegg til å ha viet fire år av sitt liv til å studere makrofagene, i troen på at de som en del av 
immunforsvaret var på hennes parti, har hun selv hatt brystkreft. Makrofagen viste seg å være en upålitelig alliert som kan gå over til fiendens side når den selv finner det for godt.

Barbara Ehrenreich forlot tidlig forskningen til fordel for formidling. Hun har skrevet mer enn 20 fagprosabøker, og bruker gjerne egne erfaringer i sitt forfatterskap. Før hun skrev boken hun er best kjent for, Nickel and dimed - on (not) getting by in America, levde hun tre måneder på lønnen hun fikk som ufaglært arbeider i supermarkeder og på serveringssteder. Brystkreften som rammet henne i 2002, resulterte i et rasende essay om hvordan det føltes å bli infantilisert gjennom rosa teddybjørner, sløyfer og bh-er (1), og en hel bok om hvorfor positiv tenkning $i k k e$ bedrer prognosen hos kreftsyke eller hindrer økonomiske nedturer (2). Ehrenreich er ofte sint, og hun er kjent for å provosere. Hun skal ha sagt at «det eneste jeg angrer ved mine egne to aborter, er at de kostet penger jeg ellers kunne brukt på hyggeligere aktiviteter, som å ta med barna på kino eller i fornøyelsesparker» (3). Er hun verdt å lytte til?

Ja. Ehrenreich er blitt gammel, og skriver om det i sin siste bok, Natural causes (4). Med utgangspunkt i de svikefulle makrofagene hevder hun at vår oppfatning av kroppen som en helhet er feil. Kroppen er sammensatt av individuelle celler som til dels samarbeider om fellesskapets beste (liv, helse), men som også har egoistiske mål. Kreftceller oppstår tross alt som en del av «selvet». I kapittelet «Tiny minds» beskriver hun fenomenet "cellular decision making», altså beslutninger som tas på enkeltcellenivå, uten påvirkning fra gener eller miljø. Hun påstår ikke at individuelle celler tar bevisste beslutninger, men at de, på samme måte som mennesket, handler ut fra et konglomerat av innkomne signaler. Jeg har ikke nok kunnskap om cellebiologi til å si om dette er riktig eller galt, men tanken er skremmende. For hvis kroppen ikke er en funksjonell enhet, men en samling celler med egne meninger hvem er det da som bestemmer? Ingen, ifølge Ehrenreich: «There is no one in charge.»

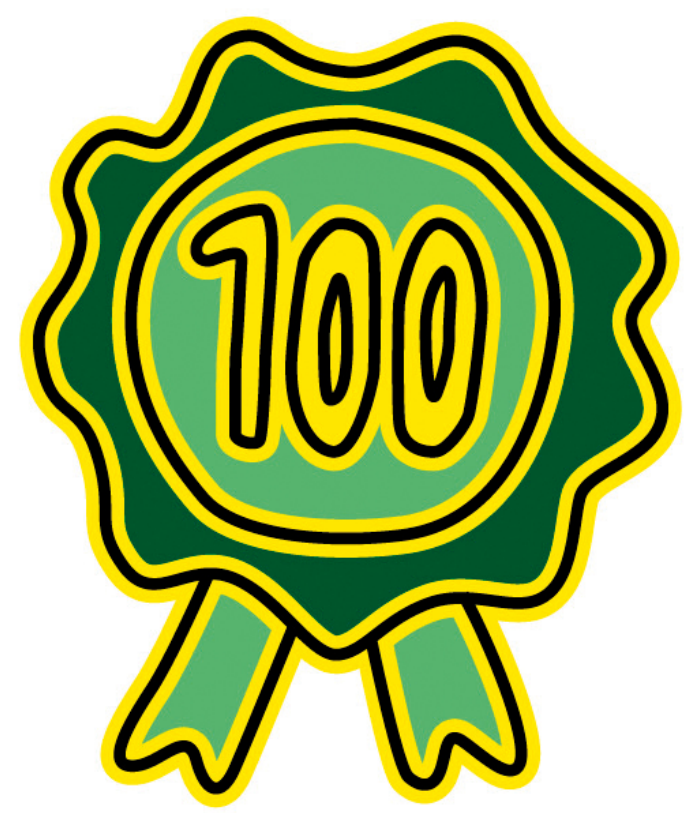

Mangelen på kontroll er et kjernepunkt i boken. For Natural causes er verken en lærebok i cellebiologi eller en biografi om aldring. Den er heller en aldrende naturviter og samfunnsdebattants analyse av verden slik hun ser den. Ehrenreich håndterer temaene hun er opptatt av (og det er, ifølge henne selv, «alt») med en erfaren filmfotografs eleganse: Hun zoomer inn på makrofagene, ut igjen til menneskekroppen, og videre ut til samfunnet. Og stopper hver gang hun finner noe å forarge seg over. Det er ofte, og det dreier seg som regel om rike, hvite menn som har tjent penger på andres usikkerhet eller uhelse. Inkludert leger.

Ehrenreich beskriver møtet mellom pasient og lege som et ritual. Hun siterer en artikkel skrevet i 1956 av en amerikansk antropolog, «Body ritual among the Nacirema» («Nacirema» 
er «American» stavet baklengs), der sykehus beskrives som templer hvor pasientene ligger forsvarsløse i sengen, badet i smerte, mens medisinmennene fra tid til annen kommer innom og stikker magiske nåler i pasientenes kjøtt: «At disse tempelseremoniene ikke nødvendigvis helbreder, men tvert imot kan føre til døden, reduserer ikke menneskenes tro på medisinmennene» (5). Det kan være verdt å minne om det spesielle ved lege-pasientforholdet: I få andre sosiale møter forventer den ene parten tilgang til alle kroppens åpninger og alle sinnets hemmeligheter uten å måtte by på noe av seg selv. Det krever ydmykhet og respekt. Barbara Ehrenreich fødte sitt første barn i 1970, som eneste hvite pasient på et offentlig sykehus i New York. Fødselen ble satt i gang fordi vakthavende lege helst ville tilbringe kvelden hjemme. Ehrenreich skal ha sagt at det var denne opplevelsen som gjorde henne til feminist (6). Kanskje skapte den også hennes livslange engasjement for kvinnehelse og den like lange tendensen til å spisse blyanten ekstra grundig når hun skriver om legestanden. For kan det virkelig stemme at vi fremdeles dissekerer lik fordi det er slik vi ser for oss den ideelle pasient - som en som ligger stille, er stille og ikke protesterer?

Ehrenreich selv har ikke tenkt å oppsøke lege oftere enn nødvendig. 77 år gammel synes hun at hun er gammel nok til å dø. Det betyr ikke at hun ikke ønsker å leve. Men heller enn å tilbringe tiden på legens kontor med blodtrykksmålinger, mammografier og koloskopier vil hun tilbringe den på sitt eget for å lese, skrive og tenke. Hun har ingen tro på at 80 er det nye 6o, eller på at aldring kan være «vellykket» (eller mislykket). Alderdommen, når det kommer til stykket, er et opprør i egen kropp. Det er som det skal være, mener Ehrenreich. Gamle mennesker kan ikke reprodusere seg eller gjøre nytte for seg. Skal naturen gå sin gang, må de gamle bli syke og dø, slik kroppens gamle og ubrukelige celler blir syke og dør. Makrokosmos skal gjenspeile mikrokosmos.

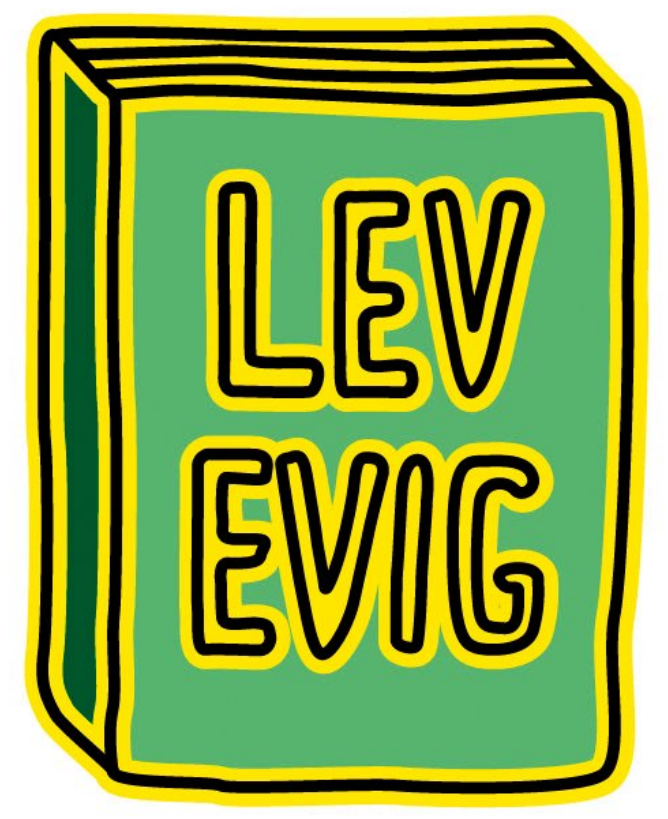

Bevegelser og slagord som påstår at sykdommer og funksjonsnedsettelser som normalt følger med alderen, kan motvirkes, unngås eller utsettes, har Ehrenreich derfor lite til overs for. Spesielt hvis de fører til at noen tjener penger. Den amerikanske legen Henry S. Lodge skapte sammen med sin pasient, Chris Cowley, en multimillionbedrift med bevegelsen "Younger next year». Cowley holder gjerne foredrag der han forklarer hvordan man holder seg ung. Doktor Lodge er det derimot ikke mulig å få tak i. Han døde av prostatakreft i 2017, 58 år gammel. Ehrenreich skadefryder seg videre over (styrtrike) helseguruer som døde før tiden: Apple-sjef og veganer Steve Jobs (bukspyttkjertelkreft, 56 år gammel) og løpelegenden James Fuller Fixx, som 35 år gammel røykte 40 sigaretter om dagen og veide nesten 100 kilo. Ti år senere, da boken The complete book on running ble utgitt i USA, hadde 
han stumpet røyken og gått ned 30 kilo. Men så døde han likevel, 52 år gammel, under sin daglige løpetur. Fortsetter trenden, advarer Ehrenreich, vil alle helseguruer, og alle som har fulgt deres råd, dø.

Selv gir Ehrenreich ingen råd. Hun vil ikke bidra med nok en selvhjelpsbok. Hennes bok er et viktig bidrag i debatten om overdiagnostikk, om enn litt unyansert. Mens mammografi ifølge Ehrenreich kan betegnes som en slags raffinert sadisme, kan en koloskopi best sammenliknes med et seksuelt overgrep: Pasienten sederes før et bøyelig rør med kamera føres gjennom anus og så langt opp og inn i pasienten som mulig. Forberedelsene, det vil si tarmt ømmingen, står for øvrig ikke tilbake for selve prosedyren. Så hvorfor ikke bare bli hjemme?

Ehrenreich er ikke dum. Det er ingen grunn til å tro at hun ikke vet forskjellen på enkeltskjebner og epidemiologiske data, eller at hun mener at alle bør avstå fra mammografi og koloskopi. Hun vil at vi skal vite at vi har et valg. At vi kan velge hvor mye av livet - den lille lommen mellom to uendeligheter av ikke-eksistens - vi skal bruke til å utsette døden og hvor mye vi skal bruke til å leve. Mennesket leter etter forklaringer og ansvar der forklaringer er vanskelige å finne og ansvar umulig å plassere (à la "Jobs jobbet for mye og spiste for mye frukt» og «Fixx var genetisk disponert for aterosklerose»). Hun refererer til aviser i USA som får klager når leserne bare får vite at David Bowie døde av kreft, og ikke hvilken form for kreft, slik at leserne ikke er i stand til å gjøre seg opp en mening om hvorvidt den tidligere storrøykeren kan lastes for sin egen død. Ved å legge ansvaret for egen helse over på enkeltindividet, fritas fellesskapet. Et overdrevent ansvar for egen helse fører til et overdrevent fokus på selvet, egen kropp og eget sinn. Ehrenreich ønsker at vi skal akseptere kroppens forfall.

\section{Barbara Ehrenreich}

NEW YORK TIMES BESTSELLING AUTHOR OF NICKEL AND DIMED

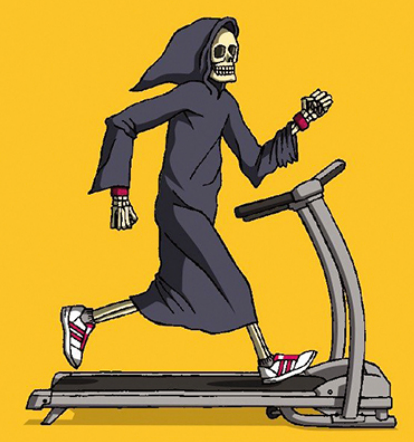

\section{Natural Causes}

AN EPIDEMIC OF WELLNESS, THE CERTAINTY OF DYING, AND KILLING OURSELVES TO LIVE LONGER

Aktuell bok. Barbara Ehrenreich. Natural causes: life, death, and the illusion of control. London: 
Aksept er et sentralt element i mindfulness, eller oppmerksomt nærvær, som det heter på norsk. Således kunne man tenke seg at Ehrenreich entusiastisk ville slutte seg til denne bølgen. Men nei. I kapittelet «The madness of mindfulness» beskriver hun heller mindfulnessbevegelsen som mer av det samme: menneskenes ønske om kontroll (over sinnet, i tillegg til kroppen) og de rikes mulighet til å tjene raske penger på andres behov. Ehrenreich bekymrer seg over hvordan digitale medier truer vår evne til konsentrasjon, og anerkjenner et økende behov for å frigjøre seg fra teknologien. Men hvem er det som tjener penger på dette behovet? Jo, Silicon Valley - stedet der unge menn (det er visstnok nesten utelukkende menn) blir milliardærer nettopp gjennom å produsere teknologiske produkter som fratar oss evnen til konsentrasjon: smarttelefoner, smartklokker, nettbrett og PCer. Alle blir smarte unntatt oss. Men i stedet for å merke produktene sine med «kan føre til avhengighet» gjør Silicon Valley mer av det de kan: De henter litt hjelp fra helsevesenet og litt fra religion, og lanserer mindfulness- og meditasjonsapper som skuffer inn penger.

Ehrenreich raser kanskje mest over det skinn av vitenskap som mindfulnessbevegelsen beveger seg bak: En metastudie fra 2014 viste nemlig at meditasjonsprogrammer er effektive mot stressrelaterte symptomer - men ikke mer effektive enn andre intervensjoner som medikamenter, avspenningsøvelser eller fysioterapi (7). Det er igjen ikke selve aktiviteten Ehrenreich kritiserer, men den kommersielt drevne bølgen som skaper følelsen av at det er dette ene som hjelper, denne appen eller denne aktiviteten. Angst eller depresjon? Har du ikke lært deg å meditere, har du deg selvå takke.

Har den sinte damen noe mer å si enn at alt er feil, og at alt var bedre før? Absolutt. Det er vanskelig å oppsummere budskapet i en bok som handler om det aller meste relatert til kropp, sinn og samfunn, men det går. For Ehrenreich vil tre ting til livs: introspeksjonen, arrogansen og urettferdigheten. Helsen vår blir ikke bedre av flere undersøkelser og flere apper, men gjennom å flytte blikket fra vår egen kropp og ut i verden, og å gjøre noe med de $\emptyset$ kende økonomiske forskjellene. Hun er amerikansk, og mye av det hun skriver om er typisk for USA: den nedre middelklassen som ikke har hatt noen reell inntektsøkning siden 196o-tallet, den hvite arbeiderklassemannen hvis kultur er forsvunnet, slik urbefolkningens kultur er forsvunnet, og mangelen på utdanning og arbeid, som er den viktigste årsaken til negativ helseatferd. 


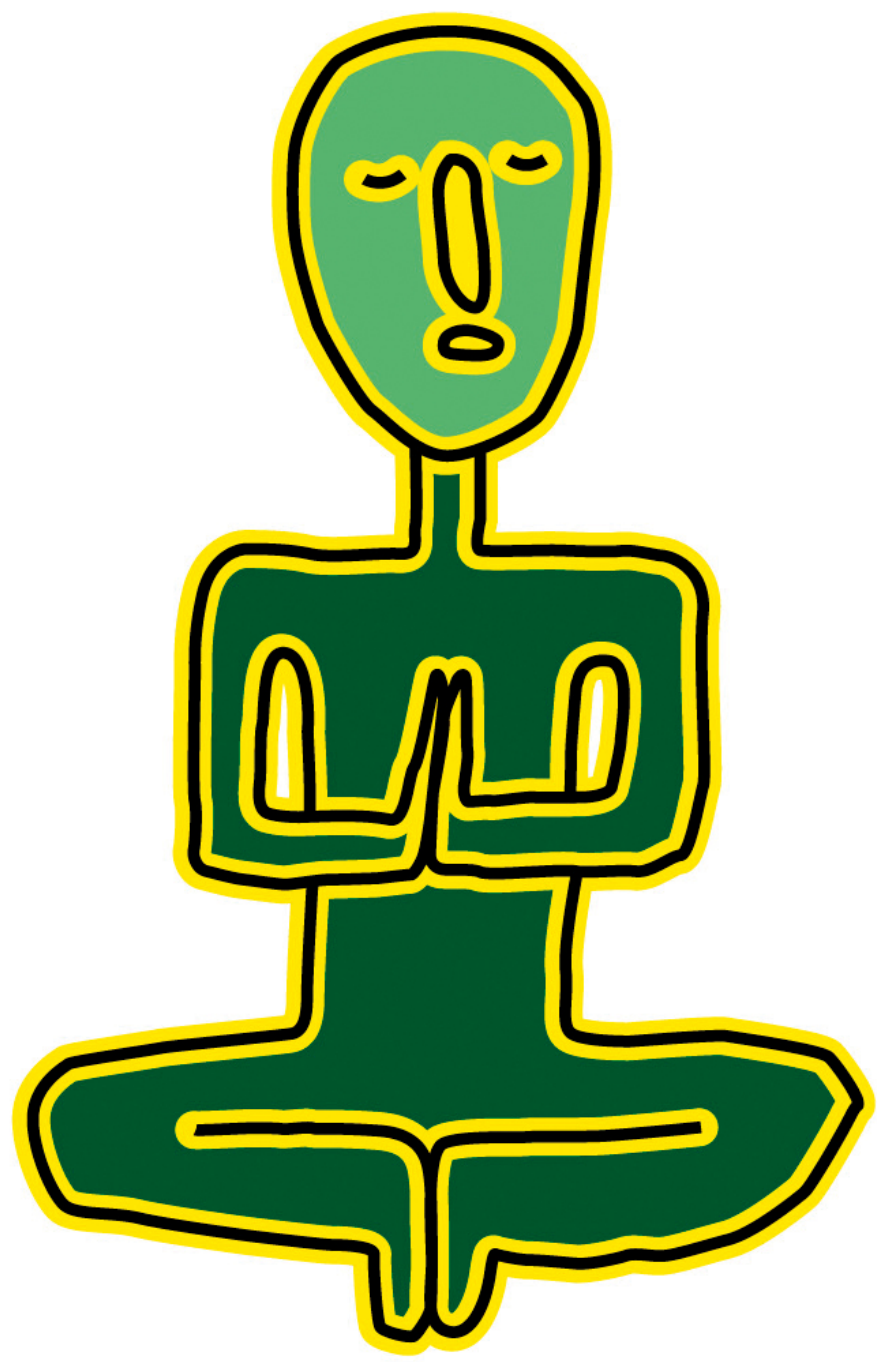

Alt er større i USA. Men også i Norge øker forskjellen mellom fattig og rik (8), og parallelt med den: forskjellen i helse. Da jeg var barn på begynnelsen av 1970-tallet, kom min mor hjem fra USA og fortalte om springvann solgt på flasker og 24-timers TV-tilbud med filmer på flere kanaler. En utopi og et drømmeland. Men fjerne kuriositeter fra Amerika har vist seg å kunne slå rot i vårt lille land. Også et privat helsevesen styrt av markedskrefter, med tilbud om «skreddersydd oppfølging» til de som har råd til det (9).

«Å bli gammel nok til å dø er å ha oppnådd noe, ikke et nederlag», skriver Ehrenreich. Hun frykter ikke døden, men gruer seg til ikke lenger å kunne følge med på alt hun er interessert i. Leserne hennes bør også grue seg. Verden trenger kloke, sinte, gamle damer (og menn) som ikke er redde for å overdrive eller provosere for at vi skal klare å se det innlysende. Og justere kursen.

\section{LITTERATUR:}

1. Ehrenreich B. Welcome to cancerland. http://www.barbaraehrenreich.com/cancerland.htm (7.10.2018).

2. Ehrenreich B. Smile or die. How positive thinking fooled America and the world. London: Granta publications, 2009.

3. Ehrenreich B. HERS. The New York Times 21.2.1985.

https://www.nytimes.com/1985/02/21/garden/hers.html (7.10.2018).

4. Ehrenreich B. Natural causes: life, death, and the illusion of control. London: Granta publications, 2018. 
5. Miner H. Body ritual among the Nacirema. American Anthropologist 1956; 58: 503-7. https://www.sfu.ca/ palys/Miner-1956-BodyRitualAmongTheNacirema.pdf(7.10.2018).

6. Barbara Ehrenreich. Wikipedia. https://en.wikipedia.org/wiki/Barbara_Ehrenreich (7.10.2018).

7. Goyal M, Singh S, Sibinga EM et al. Meditation programs for psychological stress and well-being: a systematic review and meta-analysis. JAMA Intern Med 2014; 174:357-68. [PubMed][CrossRef]

8. Folkehelserapporten - helsetilstanden i Norge. Oslo: Folkehelseinstituttet, 2018. https://www.fhi.no/nettpub/hin/(7.10.2018).

9. Aleris Executive Health. Aleris.no. https://www.aleris.no/medisinsk-senter/executive-health/ (7.10.2018).

Publisert: 14. januar 2019. Tidsskr Nor Legeforen. DOI: 10.4045/tidsskr.18.0778

(C) Tidsskrift for Den norske legeforening 2020. Lastet ned fra tidsskriftet.no 